\title{
Inadequate dietary intake of minerals: prevalence and association with socio-demographic and lifestyle factors
}

\author{
Cristiane H. Sales, Mariane de M. Fontanelli, Diva A. S. Vieira, Dirce M. Marchioni and Regina M. Fisberg* \\ Departament of Nutrition, School of Public Health, University of Sao Paulo, Av. Dr. Arnaldo, 715, Cerqueira César, CEP \\ 01246-904 São Paulo, Brazil
}

(Submitted 16 June 2016 - Final revision received 16 November 2016 - Accepted 16 December 2016 - First published online 23 January 2017)

\section{Abstract}

This cross-sectional, population-based study aimed to estimate the prevalence of dietary mineral inadequacies among residents in urban areas of Sao Paulo, to identify foods contributing to mineral intake and to verify possible associations between socio-demographic and lifestyle factors and mineral intake. Data were obtained from the 2008 Health Survey of Sao Paulo ( $n$ 1511; mean age $43 \cdot 6$ (sD 23.2), range 14-97 years). Dietary intake of minerals was measured using two 24-h dietary recalls. Socio-demographic and lifestyle data were collected. The prevalence of inadequate intake was estimated according to Dietary Reference Intakes methods. Associations between mineral intake and baseline factors were determined using multiple linear regression. $\mathrm{Na}$, $\mathrm{Ca}$ and $\mathrm{Mg}$ showed the highest dietary inadequacies. Some age/sex groups had lower intakes of $\mathrm{P}, \mathrm{Zn}, \mathrm{Cu}$ and $\mathrm{Se}$. Rice, beans and bread were the main foods contributing towards mineral intake. Female sex was negatively associated with K, Na, P, Mg, Zn and Mn intakes. All age groups were positively associated with the intakes of K, P, Mg and Mn. Family income above one minimum wage was positively associated with Se intake. Living in a household whose head completed $\geq 10$ years of education was positively associated with $\mathrm{Ca}$ and negatively associated with $\mathrm{Na}$ intake. Former smoker status was negatively associated with Ca intake. Current smoker status was inversely associated with $\mathrm{K}, \mathrm{Ca}, \mathrm{P}$ and $\mathrm{Cu}$ intakes. Sufficient physical activity was positively associated with $\mathrm{K}$, Ca and $\mathrm{Mg}$ intakes. Overall, the intakes of all major minerals were inadequate and were influenced by socio-demographic and lifestyle factors.

\section{Key words: Diet: Micronutrients: Deficiency: Epidemiological surveys: Nutritional assessment}

Brazil, similar to other developing countries, experiences a dual scenario characterised by diseases related to nutritional deficiency and to overweight ${ }^{(1)}$, commonly found in countries undergoing nutritional transition. In this context, micronutrient intake may be affected ${ }^{(1-6)}$, highlighting the importance of micronutrient intake monitoring. The practice of nutritional monitoring is useful to guide public policies focused at preventing deficiency diseases and chronic non-communicable diseases $(\mathrm{NCD})^{(1,2)}$

The role of minerals for human health is undeniable. However, there is a paucity of knowledge regarding the adequacy of mineral intake within the population. Methods that compare habitual intake with dietary requirements have been used to identify individuals at potential risk $^{(6)}$. It is also important to identify factors that influence mineral intake, as such knowledge can assist in creating targeted public policies focusing on minerals, whose intake among the population is typically low. Vlismas et al. ${ }^{(7)}$ suggest that socio-economic status may influence dietary habits, with education level being a consistent predictor of health, more so than household income or occupation. Other studies suggest that anthropometric status may influence mineral intake adequacy ${ }^{(2,8)}$, which might be explained by the adoption of unhealthier diets, especially by people of low socio-economic status ${ }^{(9)}$.

Given this background, our study aimed to estimate the prevalence of dietary mineral inadequacies in a representative sample of residents from urban areas of Sao Paulo, to identify foods that contribute towards mineral intake and to verify the possible association between socio-demographic and lifestyle factors and mineral intake.

\section{Methods}

This survey was approved by the Ethics Committee on Research of the Faculty of Public Health, University of Sao Paulo (Certificate of Presentation for Ethical Appreciation (CAAE) no. $26800414 \cdot 1 \cdot 0000 \cdot 5421)$. Written informed consent was obtained from all individuals, or from their proxies, before commencement of the study.

\section{Study population}

This study examined data from the 2008 Health Survey of Sao Paulo ('Inquérito de Saúde de São Paulo'; ISA-Capital), a cross-sectional,

Abbreviations: $24 \mathrm{HR}, 24-\mathrm{h}$ dietary recall; NCD, non-communicable disease.

* Corresponding author: R. M. Fisberg, email rfisberg@usp.br 
population-based survey that used a complex, stratified, multistage probability sample design to create a representative sample of non-institutionalised residents from urban areas of Sao Paulo, south-eastern Brazil.

Sample recruitment was performed in two stages. First, seventy census tracts were randomly selected from all urban census tracts in Sao Paulo. Second, 16607 households within these census tracts were randomly selected and stratified by the following domains: (1) infants ( $<1$ year; both sexes), (2) children (1-11 years; both sexes), (3) male adolescents (12-19 years), (4) female adolescents (12-19 years), (5) male adults (20-59 years), (6) female adults (20-59 years), (7) male elderly ( $\geq 60$ years) and (8) female elderly ( $\geq 60$ years). Different sampling fractions were used - based on the proportion of each age/sex group in the population of the urban areas sampled - to preserve the representativeness of each domain. The sample size was calculated on the basis of a prevalence of 0.5 with a sample error of 0.07 at a $5 \%$ significance level and design effect of 1.5 .

A total of 3271 individuals participated. Of these, 2691 individuals were aged 12 years and older, and were invited to have a dietary assessment performed. Pregnant or lactating women were excluded. Of those who had their diets assessed, 1511 individuals aged 14 years and older were considered. The cut-off point of 14 years was established to maintain the life stage (age) groups defined in the Dietary Reference Intakes: 9-13 years: puberty; 14-18 years: adolescence; 19-30 years: young adulthood; 30-50 years: middle age; 51-70 years: adulthood; and >70 years: older adults ${ }^{(10)}$. These age groups, reflecting the life stages, were used for the analysis of data in the present study. The survey response rate was $77 \%$. The findings presented here are based on the complete case analysis. The low percentage of missing values was likely missing at random or missing completely at random and will likely have minimal impact on associations. No additional information is available on those who refused to respond.

\section{Data entry and databases}

Trained interviewers visited the selected households to conduct individual interviews based on a structured questionnaire, assessing the following: socio-demographic (sex, age, education level, income) and lifestyle (smoking status, leisure-time physical activity, BMI, dietary habits) factors.

Sex was classified as male or female. Age at the date of interview was considered in complete years, and was used to group individuals according to the life stages of Dietary Reference Intakes. Educational level of the household head was defined as the number of years of education completed by the head of the family, categorised as $<10$ years (elementary school or less) or $\geq 10$ years (high school or more). Categories of family income per capita were calculated using the arithmetic mean of the sum of all family members' total monetary income - that is, each family member's income averaged out over the number of family members. The prevailing minimum wage established by the Brazilian government at the time of data collection was US\$ 258.39 ( R \$ 415.00), considering the exchange rate on 1 July 2008. Family income was categorised as $\leq 1$ minimum wage per capita or $>1$ minimum wage per capita. Smoking behaviour was classified as 'never', 'former' or 'current' smoker, according to the answers provided in the structured questionnaire. Leisuretime physical activity was assessed using relevant questions from the long International Physical Activity Questionnaire ${ }^{(11)}$, and was classified as 'insufficient' or 'sufficient', according to interpretations by Haskell et al. ${ }^{(12)}$ and Nelson et al. ${ }^{(13)}$. Sufficient physical activity comprised at least $30 \mathrm{~min}$ of moderate-intensity exercise daily, $5 \mathrm{~d}$ /week, or at least $20 \mathrm{~min}$ of vigorous exercise daily, $3 \mathrm{~d} /$ week; otherwise, it was considered as insufficient physical activity. Using self-reported height and weight, BMI was calculated as the quotient of weight $(\mathrm{kg})$ over height squared $\left(\mathrm{m}^{2}\right)$ and classified according to their life stage ${ }^{(14-16)}$.

Data from two non-consecutive, 24-h dietary recalls (24HR) were collected by trained interviewers: one during the interview conducted in the selected households and the other by telephone. The dietary interviews were conducted using the United States Department of Agriculture's (USDA) Multiple-Pass Method and the USDA's Automated Multiple-Pass Method, respectively. These methods guide the individual through five steps: (1) quick list - the interviewee lists, without interruption, all foods and beverages consumed the previous day; (2) forgotten foods list - the interviewer repeats the list of foods and beverages mentioned by the interviewee to identify foods that may have been forgotten; (3) time and occasion - the interviewee elaborates on the time he/she consumed foods and on what he/she considers to be a meal; (4) detail cycle - the interviewee provides descriptions and amounts of each food reported, and the interviewer reviews each occasion and the interval between occasions; and (5) final review probe - the interviewer repeats all information with the intention of collecting data on additional foods not remembered earlier ${ }^{(17)}$. The $24 \mathrm{HR}$ were conducted to include all days of the week and all seasons of the year.

\section{Assessment of dietary mineral intake}

The following minerals were considered in this study: $\mathrm{K}, \mathrm{Na}, \mathrm{Ca}$, $\mathrm{P}, \mathrm{Mg}, \mathrm{Zn}, \mathrm{Mn}, \mathrm{Cu}$ and Se. Nutrition Data System for Research software, version 2007 (Nutrition Coordinating Centre, University of Minnesota), was used to compute data obtained by the $24 \mathrm{HR}$. After entering data of $24 \mathrm{HR}$, the energy intake values were checked to identify possible mistakes in data collection and entry. Subsequently, foods' mineral values were reviewed using local information from Brazilian food tables ${ }^{(18,19)}$, and, when necessary, the mineral content was corrected to approximate the local reality using the data correction routine of Stata software (version 13.0; StataCorp LP).

Usual dietary intake of minerals was estimated using statistical modelling techniques incorporated in Multiple Source Method programme, a web-based tool used for estimating usual dietary intakes of nutrients and foods consumed by populations and individuals. The usual dietary intake was estimated in a three-step procedure. First, the probability of nutrient intake for each individual was estimated. Second, the usual amount of food intake in days of consumption was estimated. Finally, the above values were multiplied by each other to estimate the usual daily intake for each individual. The programme makes use of covariate information to improve the modelling of 
consumption probability and intake amount to estimate the distribution of usual intake ${ }^{(20)}$. Sex and age were the covariates used to adjust the modelling.

The prevalence of individual inadequate dietary intakes of $\mathrm{Ca}$, $\mathrm{P}, \mathrm{Mg}, \mathrm{Zn}, \mathrm{Cu}$ and Se was determined using the estimated average requirement (EAR) cut-off point approach, a simplification of the probability method, which estimates the proportion of individuals with usual intakes below the EAR (median requirement). Dietary $\mathrm{K}$ and $\mathrm{Mn}$ intakes were assessed for comparison with the adequate intake (AI), and the proportion of individuals with usual intakes equal to or greater than the AI value was determined. $\mathrm{Na}$ intake was assessed by risk of adverse effects using the tolerable upper intake level, which estimates the proportion of individuals potentially at risk for adverse effects ${ }^{(10)}$. These processes were conducted for each sex and age group.

A list of foods contributing to mineral intake was obtained, taking into account the sampling design, as suggested by Block et al. ${ }^{(21)}$. In brief, all foods consumed in the first $24 \mathrm{HR}$ were classified into food groups according to frequency of consumption and similarity of mineral content. If the food was consumed fewer than five times, it was grouped with other food items according to the similarity of mineral content - for example, smoothies of papaya, banana, apple, avocado and/or strawberry. If consumed at least five times, the food was kept without grouping - for example banana. Once classified, the percentage of minerals contributed was calculated using sample weighting, and the foods were sequenced in rank order of contribution.

\section{Statistical analysis}

Statistical analyses were performed using the survey data commands available in Stata software, which consider the sampling weights (probability weights), clustering and stratification of the survey design ${ }^{(22)}$. A $5 \%$ significance level was considered.

Socio-demographic and health-risk lifestyle factors were expressed as relative frequencies. Mineral intakes are presented as means, standard errors and percentiles stratified by life stage and sex. In order to reduce the errors associated with dietary measurements, the intake of minerals was adjusted according to the total energy intake using the residual method ${ }^{(23)}$. Multiple linear regression methods were used to verify the relationships between mineral intakes (dependent variables) and socio-demographic and lifestyle factors (independent variables). All regression models were adjusted for BMI and energy intake.

\section{Results}

In total, 1511 individuals were assessed. Of these, 58.1\% were women, $63.6 \%$ of household heads completed $<10$ years of education, $50.7 \%$ earned more than one minimum wage per capita, $66.6 \%$ self-reported as never smokers (18.1\% were former smokers), $86.9 \%$ engaged in insufficient leisure-time physical activity and $51.9 \%$ had healthy weight (42.5\% were overweight or obese; Table 1). Their energy intakes are presented in Table 1

Among the minerals assessed, the prevalence of inadequate intake was highest for $\mathrm{Na}, \mathrm{Ca}$ and $\mathrm{Mg}$; this was consistent across all life stages (age groups). The prevalence of inadequate intake varied from 50.0 to $95.4 \%$ for $\mathrm{Na}, 77.9$ to $99.8 \%$ for $\mathrm{Ca}$ and 82.9 to $99.5 \%$ for $\mathrm{Mg}$. Adolescents had a considerable prevalence of low dietary P intake, especially female adolescents (Tables 2 and 3). Almost none of the individuals had a $\mathrm{K}$ intake equal to or above the AI (Table 4).

In some age-/sex-stratified groups, $>20 \%$ of individuals had inadequate intakes of $\mathrm{Zn}, \mathrm{Cu}$ and $\mathrm{Se}$. Men aged $>19$ years were more susceptible to inadequate $\mathrm{Zn}$ intakes than women, and this inadequacy worsened with age. Unlike $\mathrm{Zn}, \mathrm{Cu}$ intake inadequacy did not worsen with age, and the highest prevalence of inadequate $\mathrm{Cu}$ intake was among women. Female adolescents and adults ( $\geq 31$ years) had lower Se intakes than men, which became more pronounced with age (Tables 2 and 3). A considerable proportion of individuals had $\mathrm{Mn}$ intakes equal to or above the AI: $64 \cdot 3-81 \cdot 8 \%$ for men and $77 \cdot 2-90 \cdot 3 \%$ for women (Table 4).

The ten foods listed in Table 5 (online Supplementary Tables S5. 1 and S5.2) contributed to about $60 \%$ of the total mineral intake. Overall, white rice, brown beans and French bread were the major foods contributing to dietary mineral intake in the sample assessed. Brown beans was among the top five mineral contributors; it was not listed in the top 10 only for Se (general: 132th position; men: 105th position; women: 148th position). White rice and French bread emerged as contributors to all minerals assessed: white rice stayed in the top three foods for most minerals, and French bread was in the top six foods for all minerals. Beef, chicken and milk provided a share of some minerals. Milk was the main contributor of $\mathrm{Ca}$. Meat (beef, chicken, pork and fish) contributed to all minerals except Mn. However, Mn was the only mineral that had among its top 10 food contributors vegetables (lettuce, 8th position (men: 9th; women: 9th)) and whole-grain foods (whole-wheat bread, 5th position (general, men and women)). In addition, banana contributed to Mn (6th (men: 6th; women: 6th)), K (9th (men: 10th; women: 6th)) and $\mathrm{Mg}$ (9th (men: 9th; women: 7 th)) intakes, and raw tomato contributed to K (8th (men: 8th; women: 7th)) and $\mathrm{Cu}$ (10th (men: 14th; women: 12th)), as well as, only for men, $\mathrm{Ca}$ (9th) intakes.

In the multiple linear regression model tested (Table 6), significant positive associations were identified between intake of $\mathrm{Ca}$ and household head education level $\geq 10$ years and age $\geq 51$ years; intakes of $\mathrm{K}, \mathrm{P}$ and $\mathrm{Mg}$ and all life stages (age groups); intakes of $\mathrm{Na}$ and $\mathrm{Mn}$ and life stage 31-50 years; intakes of $\mathrm{Na}, \mathrm{Ca}$, $\mathrm{Mn}$ and $\mathrm{Cu}$ and life stage 51-70 years; intakes of $\mathrm{Ca}$ and $\mathrm{Mn}$ and life stage $>70$ years; intake of Se and family income more than one minimum wage; and intakes of $\mathrm{K}, \mathrm{Ca}$ and $\mathrm{Mg}$ and sufficient physical activity.

Significant negative associations were identified between female sex and intakes of $\mathrm{K}, \mathrm{Na}, \mathrm{P}, \mathrm{Mg}, \mathrm{Zn}$ and $\mathrm{Mn}$; household head education level $\geq 10$ years and intake of $\mathrm{Na}$; former smoker status and intake of $\mathrm{Ca}$; and between current smoker status and intakes of $\mathrm{K}, \mathrm{Ca}, \mathrm{P}$ and $\mathrm{Cu}$.

\section{Discussion}

Of the minerals assessed in the present study, the only one with probably no likely risk of inadequacy in urban residents of Sao Paulo was Mn. Mn is an essential mineral that functions as 
Table 1. Baseline characteristics of urban residents in Sao Paulo: Inquérito de Saúde de São Paulo; ISA-Capital study, 2008 (Numbers, percentages, mean values and standard deviations)

\begin{tabular}{|c|c|c|c|c|c|c|c|c|c|c|c|c|}
\hline \multirow[b]{2}{*}{ Characteristics } & \multicolumn{4}{|c|}{ Men } & \multicolumn{4}{|c|}{ Women } & \multicolumn{4}{|c|}{ Total } \\
\hline & $n$ & $\%$ & Mean & SD & $n$ & $\%$ & Mean & SD & $n$ & $\%$ & Mean & SD \\
\hline Sex & 633 & 41.8 & - & - & 878 & $58 \cdot 1$ & - & - & 1511 & $100 \cdot 0$ & - & - \\
\hline Age (years) & - & - & $40 \cdot 9$ & $23 \cdot 4$ & - & - & $45 \cdot 6$ & $22 \cdot 9$ & - & - & $43 \cdot 6$ & $23 \cdot 2$ \\
\hline \multicolumn{13}{|l|}{ Household head education } \\
\hline$\leq 10$ years of education & 374 & $59 \cdot 6$ & - & - & 573 & $66 \cdot 6$ & - & - & 947 & $63 \cdot 6$ & - & - \\
\hline$>10$ years of education & 254 & $40 \cdot 4$ & - & - & 287 & $33 \cdot 4$ & - & - & 541 & $36 \cdot 4$ & - & - \\
\hline \multicolumn{13}{|l|}{ Family income* ${ }^{*}$} \\
\hline$\leq 1$ minimum wage per capita & 290 & $45 \cdot 8$ & - & - & 455 & $51 \cdot 8$ & - & - & 745 & $49 \cdot 3$ & - & - \\
\hline$>1$ minimum wage per capita & 343 & 54.2 & - & - & 423 & $48 \cdot 2$ & - & - & 766 & $50 \cdot 7$ & - & - \\
\hline \multicolumn{13}{|l|}{ Smoking behaviour } \\
\hline Non-smoker & 382 & $60 \cdot 4$ & - & - & 624 & $71 \cdot 1$ & - & - & 1006 & $66 \cdot 6$ & - & - \\
\hline Former smoker & 139 & $22 \cdot 0$ & - & - & 134 & $15 \cdot 3$ & - & - & 273 & $18 \cdot 1$ & - & - \\
\hline Current smoker & 112 & $17 \cdot 7$ & - & - & 120 & 13.7 & - & - & 232 & $15 \cdot 4$ & - & - \\
\hline \multicolumn{13}{|l|}{ Leisure-time physical activity } \\
\hline Insufficient physical activity & 511 & $80 \cdot 9$ & - & - & 801 & $91 \cdot 2$ & - & - & 1312 & $86 \cdot 9$ & - & - \\
\hline Sufficient physical activity $\dagger$ & 121 & $19 \cdot 2$ & - & - & 77 & $8 \cdot 8$ & - & - & 198 & $13 \cdot 1$ & - & - \\
\hline \multicolumn{13}{|l|}{ BMI $\left(\mathrm{kg} / \mathrm{m}^{2}\right) \ddagger$} \\
\hline Underweight & 32 & $5 \cdot 14$ & - & - & 52 & $6 \cdot 0$ & - & - & 84 & 5.63 & - & - \\
\hline Healthy weight & 342 & 54.9 & - & - & 433 & $49 \cdot 8$ & - & - & 775 & 51.9 & - & - \\
\hline Overweight and obesity & 249 & 40.0 & - & - & 385 & 44.3 & - & - & 634 & 42.5 & - & - \\
\hline \multicolumn{13}{|l|}{ Energy intake $(\mathrm{kJ} / \mathrm{d})$} \\
\hline $14-18$ years & 181 & $28 \cdot 6$ & $10741 \cdot 2$ & $3086 \cdot 5$ & 176 & $20 \cdot 0$ & $8409 \cdot 8$ & $2857 \cdot 7$ & 357 & $23 \cdot 6$ & $9591 \cdot 8$ & $3192 \cdot 8$ \\
\hline $19-30$ years & 103 & $16 \cdot 3$ & $9937 \cdot 8$ & $2968 \cdot 1$ & 118 & $13 \cdot 4$ & $7722 \cdot 8$ & $1901 \cdot 2$ & 221 & $14 \cdot 6$ & $8755 \cdot 0$ & 2689.5 \\
\hline $31-50$ years & 117 & 18.5 & $8943 \cdot 3$ & $2616 \cdot 3$ & 191 & $21 \cdot 8$ & $6678 \cdot 1$ & 1738.5 & 308 & $20 \cdot 4$ & $7538 \cdot 3$ & $2381 \cdot 1$ \\
\hline $51-70$ years & 148 & $23 \cdot 4$ & $7500 \cdot 2$ & $2079 \cdot 4$ & 235 & $26 \cdot 8$ & $5935 \cdot 0$ & $1456 \cdot 5$ & 383 & $25 \cdot 4$ & $6539 \cdot 6$ & $1882 \cdot 8$ \\
\hline$>70$ years & 84 & $13 \cdot 3$ & $6850 \cdot 0$ & $1762 \cdot 3$ & 158 & $18 \cdot 0$ & $5360 \cdot 9$ & $1401 \cdot 2$ & 242 & $16 \cdot 0$ & $5877 \cdot 7$ & $1689 \cdot 1$ \\
\hline \multicolumn{13}{|l|}{ Energy intake (kcal/d) } \\
\hline $14-18$ years & 181 & $28 \cdot 6$ & $2567 \cdot 2$ & $737 \cdot 7$ & 176 & $20 \cdot 0$ & $2010 \cdot 0$ & 683.0 & 357 & $23 \cdot 6$ & 2292.5 & $763 \cdot 1$ \\
\hline $19-30$ years & 103 & $16 \cdot 3$ & $2375 \cdot 2$ & 709.4 & 118 & 13.4 & $1845 \cdot 8$ & 454.4 & 221 & $14 \cdot 6$ & 2092.5 & $642 \cdot 8$ \\
\hline $31-50$ years & 117 & 18.5 & 2137.5 & $625 \cdot 3$ & 191 & $21 \cdot 8$ & $1596 \cdot 1$ & 415.5 & 308 & $20 \cdot 4$ & $1801 \cdot 7$ & $569 \cdot 1$ \\
\hline $51-70$ years & 148 & $23 \cdot 4$ & $1792 \cdot 6$ & $497 \cdot 0$ & 235 & $26 \cdot 8$ & 1418.5 & $348 \cdot 1$ & 383 & $25 \cdot 4$ & $1563 \cdot 0$ & $450 \cdot 0$ \\
\hline$>70$ years & 84 & $13 \cdot 3$ & $1637 \cdot 2$ & $421 \cdot 2$ & 158 & $18 \cdot 0$ & $1281 \cdot 3$ & 334.9 & 242 & $16 \cdot 0$ & 1404.8 & 403.7 \\
\hline
\end{tabular}

${ }^{*}$ Family income per capita is the sum of all family members' monetary income averaged out over the number of family members. Minimum wage $=$ US $\$ 258.39(\mathrm{R} \$ 415 \cdot 00)$.

$\dagger$ Sufficient physical activity: moderate-intensity exercise for at least $30 \mathrm{~min}$ daily on $5 \mathrm{~d} /$ week or vigorous-intensity exercise for at least $20 \mathrm{~min}$ daily on $3 \mathrm{~d} /$ week; otherwise, it was considered as insufficient physical activity ${ }^{(12,13)}$.

‡ BMI classifications: 14-19 years: underweight, $\mathrm{BMI}<3$ rd percentile; healthy weight, $\mathrm{BMI}>3 \mathrm{rd}$ percentile and $<85$ th percentile; overweight, BMI $>85$ th percentile and $<97$ th percentile; obese, BMI $>97$ th percentile ${ }^{(14)} ; 20-59$ years: underweight, BMl $<18.5 \mathrm{~kg} / \mathrm{m}^{2}$; healthy weight, BMI $18.5-24.9 \mathrm{~kg} / \mathrm{m}^{2} ;$ overweight, BMI $25.0-29.9 \mathrm{~kg} / \mathrm{m}^{2}$; obese, $\mathrm{BMI} \geq 30 \mathrm{~kg} / \mathrm{m}^{2(15)}$; and $\geq 60$ years: underweight, $\mathrm{BMl}<23 \mathrm{~kg} / \mathrm{m}^{2}$; healthy weight, BMl 23.0-27.9 kg/m²; overweight, BMl $28-29 \cdot 9 \mathrm{~kg} / \mathrm{m}^{2} ;$ obese, BMI $\geq 30 \mathrm{~kg} / \mathrm{m}^{2(16)}$.

an antioxidant and plays an important role in amino acid, cholesterol and carbohydrate metabolism ${ }^{(24)}$. However, a few studies have assessed levels of dietary Mn intake. Hence, the RDA of Mn has not yet been established, making it difficult to assert whether there is, in fact, adequacy of intake ${ }^{(24)}$.

Similar to Mn, the RDA for K and Na could not be derived ${ }^{(25)}$. High levels of dietary $\mathrm{Na}$ and lower levels of dietary $\mathrm{K}$ were observed among both sexes and all life stages (age groups) assessed. Inadequate $\mathrm{K}$ and suboptimal $\mathrm{Na}$ intake has also been observed globally ${ }^{(1,26-29)}$. This combination is considered harmful to health because of the high rates of morbidity and mortality related to CVD. On the other hand, high sodium chloride intake results in increased urinary $\mathrm{Na}$ excretion, which leads to loss of other minerals, and thus predisposes the body to changes in homoeostasis ${ }^{(30)}$. According to Powles et al. ${ }^{(29)}$, Brazilian adults ( $\geq 20$ years) have the highest dietary Na intakes ( $4110 \mathrm{mg} / \mathrm{d}$ ) in Latin America, and higher than those observed in the USA $(3610 \mathrm{mg} / \mathrm{d})$ and Canada $(3720 \mathrm{mg} / \mathrm{d})$. These authors also observed higher dietary $\mathrm{Na}$ intake in men. A possible explanation is that men generally have higher energy requirements than women. Other reasons include an increased concern with appearance and greater health consciousness among women. As evidenced by Souza et al. ${ }^{(31)}$, the present study showed that $\mathrm{Na}$ intake was provided by traditional Brazilian foods such as rice and beans and other foods such as bread, meats, pizza and salted margarine, as well as the discretionary addition of salt (especially in the form of sodium chloride) during cooking for seasoning. These foods contributed significantly as a source of $\mathrm{Na}$ intake. An increased intake of more K-rich foods such as fruits, leafy green vegetables and root vegetables - combined with a reduced intake of high-salt-content products - especially the addition of salt - could help achieve the physiological requirements for $\mathrm{K}$ and $\mathrm{Na}$ and could decrease the burden of $\mathrm{NCD}^{(25)}$.

To improve this scenario, the World Health Organization ${ }^{(32)}$ set a global target of reducing salt intake by $30 \%$ by 2025 , aiming for a salt intake of $<5 \mathrm{~g} / \mathrm{d}$. Several countries have implemented salt reduction strategies. These strategies have included engaging with the food industry to re-formulate products, establish the $\mathrm{Na}$ content targets for foods, provide consumer education and ensure front-of-pack labelling; imposing taxes on high-salt foods; and introducing interventions in public institutions ${ }^{(33)}$. In Brazil, the strategies adopted by the Ministry of Health are promoting healthy eating; providing 
Table 2. Dietary intakes of minerals, their distribution and probability of inadequacy in men residing in urban areas of Sao Paulo, according to life stage: Inquérito de Saúde de São Paulo (ISA-Capital) study, 2008

(Numbers, means values and standard deviations)

\begin{tabular}{|c|c|c|c|c|c|c|c|c|c|c|}
\hline \multirow[b]{2}{*}{ Life stages* } & \multirow[b]{2}{*}{$n$} & \multirow[b]{2}{*}{ Mean } & \multirow[b]{2}{*}{ SD } & \multicolumn{5}{|c|}{ Percentiles of minerals intake } & \multirow[b]{2}{*}{ EAR or UL† } & \multirow[b]{2}{*}{ Prevalence of inadequate intake (\%) } \\
\hline & & & & 10 & 25 & 50 & 75 & 90 & & \\
\hline \multicolumn{11}{|l|}{$\mathrm{Na}(\mathrm{mg} / \mathrm{d})$} \\
\hline $14-18$ years & 181 & $4206 \cdot 3$ & $1125 \cdot 1$ & $2732 \cdot 2$ & 3513.7 & $4182 \cdot 7$ & 4892.7 & $5672 \cdot 8$ & $1500 / 2300$ & $95.5 \dagger$ \\
\hline $19-30$ years & 103 & $4056 \cdot 6$ & $1036 \cdot 7$ & $2652 \cdot 6$ & 3273.9 & $4148 \cdot 0$ & $4966 \cdot 8$ & $5310 \cdot 7$ & $1500 / 2300$ & $95.5 \dagger$ \\
\hline $31-50$ years & 117 & $3834 \cdot 3$ & $1065 \cdot 3$ & $2445 \cdot 0$ & $3061 \cdot 2$ & 3783.5 & $4651 \cdot 0$ & $5266 \cdot 0$ & $1500 / 2300$ & $92.5 \dagger$ \\
\hline $51-70$ years & 148 & $3596 \cdot 8$ & $1080 \cdot 1$ & $2390 \cdot 4$ & $2845 \cdot 1$ & $3416 \cdot 4$ & $4162 \cdot 0$ & 5194.5 & $1300 / 2300$ & $88.5 \dagger$ \\
\hline$>70$ years & 84 & $3068 \cdot 3$ & 789.5 & $2089 \cdot 3$ & 2514.7 & 2979.9 & $3570 \cdot 6$ & $4039 \cdot 4$ & $1200 / 2300$ & $83.4 \dagger$ \\
\hline \multicolumn{11}{|l|}{$\mathrm{Ca}(\mathrm{mg} / \mathrm{d})$} \\
\hline $14-18$ years & 181 & 693.7 & $312 \cdot 2$ & 374.1 & 458.1 & 648.9 & 841.5 & 1114.7 & 1100 & $90 \cdot 3$ \\
\hline $19-30$ years & 103 & 594.3 & $265 \cdot 6$ & $273 \cdot 2$ & 393.2 & 584.4 & 768.6 & $916 \cdot 6$ & 800 & 77.9 \\
\hline $31-50$ years & 117 & 563.1 & 227.7 & 305.4 & 396.9 & 518.2 & $720 \cdot 3$ & $906 \cdot 3$ & 800 & $85 \cdot 1$ \\
\hline $51-70$ years & 148 & $556 \cdot 6$ & 243.6 & $278 \cdot 2$ & 382.1 & $510 \cdot 6$ & 673.9 & 934.0 & 800 & $84 \cdot 1$ \\
\hline$>70$ years & 84 & 577.3 & 239.9 & $313 \cdot 2$ & 427.6 & 562.5 & 703.1 & 871.7 & 1000 & $96 \cdot 1$ \\
\hline \multicolumn{11}{|l|}{$P(\mathrm{mg} / \mathrm{d})$} \\
\hline $14-18$ years & 181 & $1249 \cdot 2$ & 386.9 & 804.8 & $1027 \cdot 1$ & $1192 \cdot 6$ & $1428 \cdot 3$ & $1689 \cdot 6$ & 1055 & 30.9 \\
\hline $19-30$ years & 103 & $1201 \cdot 1$ & 397.7 & $772 \cdot 9$ & $924 \cdot 6$ & $1138 \cdot 0$ & $1489 \cdot 8$ & 1719.9 & 580 & $5 \cdot 9$ \\
\hline $31-50$ years & 117 & 1119.5 & $302 \cdot 4$ & $745 \cdot 2$ & $910 \cdot 8$ & 1112.5 & $1325 \cdot 8$ & $1569 \cdot 2$ & 580 & 3.8 \\
\hline $51-70$ years & 148 & $1079 \cdot 3$ & 351.2 & 634.8 & $825 \cdot 6$ & $1054 \cdot 2$ & 1284.9 & $1546 \cdot 8$ & 580 & 7.8 \\
\hline$>70$ years & 84 & 975.4 & 264.4 & $636 \cdot 3$ & 811.9 & 973.5 & $1133 \cdot 8$ & $1292 \cdot 4$ & 580 & 6.7 \\
\hline \multicolumn{11}{|l|}{$\mathrm{Mg}(\mathrm{mg} / \mathrm{d})$} \\
\hline $14-18$ years & 181 & 263.1 & $77 \cdot 6$ & $175 \cdot 8$ & 208.8 & 258.5 & $304 \cdot 1$ & $345 \cdot 8$ & 340 & 83.9 \\
\hline $19-30$ years & 103 & 255.4 & 78.2 & 162.5 & $202 \cdot 1$ & 251.8 & $315 \cdot 8$ & 353.9 & 330 & 82.9 \\
\hline $31-50$ years & 117 & 241.7 & $62 \cdot 7$ & $158 \cdot 1$ & 199.9 & $236 \cdot 1$ & 289.7 & 334.6 & 350 & 95.8 \\
\hline $51-70$ years & 148 & 237.5 & 68.5 & $156 \cdot 8$ & 191.6 & $225 \cdot 6$ & 273.6 & 345.1 & 350 & 95.0 \\
\hline$>70$ years & 84 & $219 \cdot 2$ & 51.3 & 158.5 & 185.0 & 220.0 & 250.8 & 287.5 & 350 & 99.5 \\
\hline \multicolumn{11}{|l|}{$\mathrm{Zn}(\mathrm{mg} / \mathrm{d})$} \\
\hline $14-18$ years & 181 & $14 \cdot 8$ & 4.8 & 9.2 & $11 \cdot 7$ & 14.5 & $18 \cdot 4$ & 20.5 & 8.5 & 9.3 \\
\hline $19-30$ years & 103 & $14 \cdot 4$ & 4.4 & 9.5 & 11.4 & $13 \cdot 6$ & $17 \cdot 2$ & $20 \cdot 2$ & 9.4 & $13 \cdot 1$ \\
\hline $31-50$ years & 117 & $12 \cdot 8$ & $4 \cdot 1$ & $7 \cdot 8$ & $10 \cdot 4$ & $12 \cdot 1$ & $15 \cdot 1$ & $17 \cdot 6$ & $9 \cdot 4$ & $20 \cdot 1$ \\
\hline $51-70$ years & 148 & 11.5 & 3.7 & 7.6 & $9 \cdot 1$ & $10 \cdot 8$ & $13 \cdot 6$ & $15 \cdot 4$ & 9.4 & 28.4 \\
\hline$>70$ years & 84 & $10 \cdot 3$ & $2 \cdot 9$ & $7 \cdot 0$ & 7.9 & $10 \cdot 0$ & $12 \cdot 3$ & $13 \cdot 8$ & $9 \cdot 4$ & 37.8 \\
\hline \multicolumn{11}{|l|}{$\mathrm{Cu}(\mathrm{mg} / \mathrm{d})$} \\
\hline $14-18$ years & 181 & 1.4 & 0.4 & 0.9 & $1 \cdot 1$ & 1.3 & 1.6 & 1.8 & 0.69 & 4.4 \\
\hline $19-30$ years & 103 & 1.4 & 0.9 & 0.9 & 1.0 & 1.3 & 1.5 & $1 \cdot 8$ & 0.70 & 23.3 \\
\hline $31-50$ years & 117 & 1.2 & 0.4 & 0.8 & 1.0 & 1.1 & 1.4 & 1.7 & 0.70 & $10 \cdot 0$ \\
\hline $51-70$ years & 148 & 1.1 & 0.5 & 0.8 & 0.9 & 1.1 & $1 \cdot 2$ & 1.6 & 0.70 & $16 \cdot 9$ \\
\hline$>70$ years & 84 & 1.0 & 0.2 & 0.7 & 0.9 & $1 \cdot 0$ & $1 \cdot 1$ & $1 \cdot 2$ & 0.70 & $9 \cdot 0$ \\
\hline \multicolumn{11}{|l|}{$\operatorname{Se}(\mu \mathrm{g} / \mathrm{d})$} \\
\hline $14-18$ years & 181 & 93.0 & $30 \cdot 0$ & $59 \cdot 2$ & 73.7 & $90 \cdot 7$ & $107 \cdot 2$ & $133 \cdot 2$ & 45 & 5.5 \\
\hline $19-30$ years & 103 & 91.4 & 43.6 & $55 \cdot 2$ & $65 \cdot 8$ & 86.9 & $100 \cdot 5$ & 133.9 & 45 & 14.5 \\
\hline $31-50$ years & 117 & 81.0 & 28.6 & $48 \cdot 1$ & $61 \cdot 4$ & $75 \cdot 8$ & $97 \cdot 4$ & $118 \cdot 0$ & 45 & $10 \cdot 4$ \\
\hline $51-70$ years & 148 & $76 \cdot 0$ & 33.6 & $44 \cdot 8$ & $56 \cdot 1$ & 68.2 & 88.9 & 113.9 & 45 & 17.9 \\
\hline$>70$ years & 84 & $62 \cdot 4$ & $20 \cdot 8$ & $40 \cdot 9$ & $50 \cdot 5$ & $59 \cdot 6$ & $72 \cdot 5$ & 83.6 & 45 & $20 \cdot 1$ \\
\hline
\end{tabular}

EAR, estimated average requirement; UL, upper limit level.

* $14-18$ years: adolescence; $19-30$ years: young adulthood; $30-50$ years: middle age; $51-70$ years: adulthood; $>70$ years: older adults ${ }^{(10)}$.

† For $\mathrm{Na}$, the results are the proportion of individuals with risk of adverse effects by $\mathrm{Na}$ intakes, calculated using the UL.

education and information for healthcare and food handling and manufacturing professionals; and re-formulating processed foods ${ }^{(34)}$

In Brazil, NCD are the leading cause of all deaths (72\%) and the largest contributor to disease burden. Diabetes and hypertension have become increasingly prevalent, rising in parallel with overweight ${ }^{(35)}$. In addition to the association between dietary $\mathrm{Na}$ and $\mathrm{NCD}$, a causal link between dietary inadequacy of $\mathrm{Ca}$ and $\mathrm{Mg}$ and $\mathrm{NCD}$ has been suggested ${ }^{(36-41)}$. In the present study, the inadequacy of $\mathrm{Ca}$ and $\mathrm{Mg}$ intake was more pronounced than that of $\mathrm{Na}$; this could increase NCD. One of the reasons for $\mathrm{Mg}$ inadequacy is the low consumption of foods rich in $\mathrm{Mg}$, with most of it being derived from foods that are believed to be intermediate or low sources of this micronutrient.
The simple change from white rice $(12 \mathrm{mg} / 100 \mathrm{~g}$ of food) to whole rice ( $43 \mathrm{mg} / 100 \mathrm{~g}$ of food) could have a positive effect on $\mathrm{Mg}$ intake, especially if the other cereals were also consumed in their whole form.

Dairy products contributed towards Ca intake in the sample assessed. However, its consumption was insufficient to supply physiological needs. Other foods, which are not particularly rich in $\mathrm{Ca}$, were listed because they were consumed in large quantities. Studies have suggested that consumption of dairy products is associated with a decreased risk of CVD, type 2 diabetes and overweight ${ }^{(42-44)}$.

Intake of $\mathrm{P}$, unlike the other minerals assessed, showed considerable inadequacy among adolescents, and very low to low intake levels in the other age groups. $\mathrm{P}$ is found in nature as 
Table 3. Dietary intakes of minerals, their distribution and probability of inadequacy in women residing in urban areas of Sao Paulo, according to life stage: Inquérito de Saúde de São Paulo (ISA-Capital) study, 2008

(Numbers, mean values and standard deviations)

\begin{tabular}{|c|c|c|c|c|c|c|c|c|c|c|}
\hline \multirow[b]{2}{*}{ Life stages* } & \multirow[b]{2}{*}{$n$} & \multirow[b]{2}{*}{ Mean } & \multirow[b]{2}{*}{ SD } & \multicolumn{5}{|c|}{ Percentiles of minerals intake } & \multirow[b]{2}{*}{ EAR or UL† } & \multirow[b]{2}{*}{ Prevalence of inadequate intake (\%) } \\
\hline & & & & 10 & 25 & 50 & 75 & 90 & & \\
\hline \multicolumn{11}{|l|}{$\mathrm{Na}(\mathrm{mg} / \mathrm{d})$} \\
\hline $14-18$ years & 176 & $3147 \cdot 7$ & $1014 \cdot 8$ & $1975 \cdot 6$ & $2531 \cdot 0$ & 2939.1 & $3732 \cdot 0$ & $4286 \cdot 6$ & $1500 / 2300$ & $80.0 \dagger$ \\
\hline $19-30$ years & 118 & $3046 \cdot 8$ & $680 \cdot 6$ & $2284 \cdot 2$ & $2692 \cdot 6$ & 2978.0 & 3498.9 & $3998 \cdot 3$ & $1500 / 2300$ & $86.4 \dagger$ \\
\hline $31-50$ years & 191 & $2843 \cdot 8$ & 747.5 & 2037.5 & $2303 \cdot 3$ & 2768.9 & 3241.7 & $3696 \cdot 4$ & $1500 / 2300$ & $76 \cdot 7 \dagger$ \\
\hline $51-70$ years & 235 & $2569 \cdot 2$ & 661.8 & $1795 \cdot 3$ & $2210 \cdot 6$ & $2512 \cdot 1$ & 2870.5 & $3275 \cdot 2$ & $1300 / 2300$ & $65.5 \dagger$ \\
\hline$>70$ years & 158 & $2297 \cdot 8$ & 721.4 & $1566 \cdot 7$ & 1839.5 & $2160 \cdot 6$ & $2596 \cdot 4$ & $2972 \cdot 2$ & $1200 / 2300$ & $50 \cdot 0 \dagger$ \\
\hline \multicolumn{11}{|l|}{$\mathrm{Ca}(\mathrm{mg} / \mathrm{d})$} \\
\hline $14-18$ years & 176 & 576.9 & 231.9 & 307.8 & 398.5 & 565.1 & 699.6 & 894.6 & 1100 & 98.8 \\
\hline $19-30$ years & 118 & 555.6 & $190 \cdot 0$ & 348.5 & 424.0 & 534.6 & 649.4 & $822 \cdot 0$ & 800 & $90 \cdot 2$ \\
\hline $31-50$ years & 191 & 484.6 & $184 \cdot 0$ & $260 \cdot 8$ & 328.4 & 466.0 & $601 \cdot 8$ & 756.6 & 800 & 95.5 \\
\hline $51-70$ years & 235 & 492.5 & 183.0 & $270 \cdot 7$ & $356 \cdot 3$ & 468.4 & $602 \cdot 8$ & $734 \cdot 3$ & 1000 & $99 \cdot 7$ \\
\hline$>70$ years & 158 & $502 \cdot 6$ & $176 \cdot 9$ & $285 \cdot 7$ & $382 \cdot 7$ & $492 \cdot 3$ & $605 \cdot 7$ & 721.5 & 1000 & 99.8 \\
\hline \multicolumn{11}{|l|}{$P(\mathrm{mg} / \mathrm{d})$} \\
\hline $14-18$ years & 176 & 978.6 & $308 \cdot 0$ & $625 \cdot 9$ & $765 \cdot 4$ & 935.4 & 1145.5 & $1342 \cdot 6$ & 1055 & $59 \cdot 9$ \\
\hline $19-30$ years & 118 & $940 \cdot 0$ & $200 \cdot 3$ & 693.0 & 804.5 & 951.6 & $1070 \cdot 6$ & 1193.9 & 580 & 3.6 \\
\hline $31-50$ years & 191 & 876.6 & $233 \cdot 8$ & $592 \cdot 8$ & 708.9 & $848 \cdot 2$ & $1010 \cdot 9$ & $1189 \cdot 0$ & 580 & $10 \cdot 2$ \\
\hline $51-70$ years & 235 & 844.5 & $221 \cdot 7$ & $568 \cdot 0$ & 696.7 & 833.4 & 975.1 & $1143 \cdot 7$ & 580 & $11 \cdot 7$ \\
\hline$>70$ years & 158 & $778 \cdot 2$ & $222 \cdot 1$ & $535 \cdot 3$ & $619 \cdot 0$ & $752 \cdot 3$ & 906.6 & $1025 \cdot 8$ & 580 & $18 \cdot 7$ \\
\hline \multicolumn{11}{|l|}{$\mathrm{Mg}(\mathrm{mg} / \mathrm{d})$} \\
\hline $14-18$ years & 176 & 203.3 & $60 \cdot 4$ & 133.6 & 163.1 & 197.5 & 228.0 & $290 \cdot 2$ & 300 & 94.5 \\
\hline $19-30$ years & 118 & $198 \cdot 7$ & $46 \cdot 5$ & $142 \cdot 9$ & $165 \cdot 6$ & $195 \cdot 1$ & 233.8 & 253.6 & 255 & $88 \cdot 7$ \\
\hline $31-50$ years & 191 & 185.5 & $46 \cdot 5$ & 133.2 & 157.9 & 174.8 & $208 \cdot 2$ & $242 \cdot 0$ & 265 & $95 \cdot 6$ \\
\hline $51-70$ years & 235 & $185 \cdot 4$ & $45 \cdot 7$ & 129.5 & 154.4 & 177.9 & $212 \cdot 1$ & 258.7 & 265 & 95.9 \\
\hline$>70$ years & 158 & $172 \cdot 1$ & $44 \cdot 3$ & 124.9 & $140 \cdot 6$ & 167.9 & 198.6 & $226 \cdot 1$ & 265 & $98 \cdot 2$ \\
\hline \multicolumn{11}{|l|}{$\mathrm{Zn}(\mathrm{mg} / \mathrm{d})$} \\
\hline $14-18$ years & 176 & $11 \cdot 1$ & $3 \cdot 8$ & 6.9 & 8.3 & 10.9 & $13 \cdot 0$ & $15 \cdot 6$ & $7 \cdot 3$ & $15 \cdot 6$ \\
\hline $19-30$ years & 118 & $9 \cdot 8$ & $2 \cdot 3$ & $6 \cdot 8$ & 8.5 & $9 \cdot 4$ & $11 \cdot 1$ & $13 \cdot 1$ & $6 \cdot 8$ & $9 \cdot 7$ \\
\hline $31-50$ years & 191 & 9.4 & $2 \cdot 6$ & $6 \cdot 7$ & $7 \cdot 7$ & 9.1 & $10 \cdot 6$ & $12 \cdot 3$ & $6 \cdot 8$ & $15 \cdot 6$ \\
\hline $51-70$ years & 235 & 8.5 & 2.5 & $6 \cdot 0$ & $7 \cdot 0$ & $7 \cdot 7$ & $9 \cdot 7$ & $11 \cdot 8$ & $6 \cdot 8$ & 24.5 \\
\hline$>70$ years & 158 & 7.5 & $2 \cdot 2$ & 5.4 & $6 \cdot 1$ & 7.0 & 8.8 & $10 \cdot 4$ & $6 \cdot 8$ & 37.5 \\
\hline \multicolumn{11}{|l|}{$\mathrm{Cu}(\mathrm{mg} / \mathrm{d})$} \\
\hline $14-18$ years & 176 & $1 \cdot 14$ & 0.6 & 0.7 & 0.9 & 1.1 & 1.3 & 1.5 & 0.69 & 21.5 \\
\hline $19-30$ years & 118 & $1 \cdot 13$ & 0.9 & 0.7 & 0.9 & 1.0 & 1.2 & 1.4 & 0.70 & 30.9 \\
\hline $31-50$ years & 191 & 0.93 & 0.3 & 0.7 & 0.8 & 0.9 & 1.0 & 1.2 & 0.70 & $20 \cdot 9$ \\
\hline $51-70$ years & 235 & 0.91 & 0.3 & 0.7 & 0.7 & 0.9 & 1.0 & 1.2 & 0.70 & 23.6 \\
\hline$>70$ years & 158 & 0.81 & 0.3 & 0.6 & 0.7 & 0.8 & 0.9 & 1.1 & 0.70 & $35 \cdot 6$ \\
\hline \multicolumn{11}{|l|}{ Se $(\mu \mathrm{g} / \mathrm{d})$} \\
\hline $14-18$ years & 176 & 74.0 & $26 \cdot 2$ & $42 \cdot 7$ & $57 \cdot 0$ & 72.5 & 87.9 & $104 \cdot 1$ & 45 & 13.4 \\
\hline $19-30$ years & 118 & 69.9 & 19.9 & $44 \cdot 1$ & 59.9 & $67 \cdot 2$ & 82.4 & 93.3 & 45 & $10 \cdot 6$ \\
\hline $31-50$ years & 191 & $62 \cdot 2$ & $22 \cdot 1$ & 39.9 & 48.4 & $56 \cdot 5$ & $72 \cdot 1$ & $91 \cdot 1$ & 45 & $21 \cdot 8$ \\
\hline $51-70$ years & 235 & $59 \cdot 2$ & $20 \cdot 7$ & $37 \cdot 7$ & $45 \cdot 9$ & $55 \cdot 7$ & $69 \cdot 1$ & $77 \cdot 4$ & 45 & 24.8 \\
\hline$>70$ years & 158 & $50 \cdot 3$ & $17 \cdot 4$ & $33 \cdot 3$ & $39 \cdot 3$ & $48 \cdot 1$ & $56 \cdot 2$ & $66 \cdot 8$ & 45 & $38 \cdot 2$ \\
\hline
\end{tabular}

EAR, estimated average requirement; UL, upper limit level.

* 14-18 years: adolescence; $19-30$ years: young adulthood; 30-50 years: middle age; $51-70$ years: adulthood; $>70$ years: older adults ${ }^{(10)}$.

$\dagger$ For $\mathrm{Na}$, the results are the proportion of individuals with risk of adverse effects by $\mathrm{Na}$ intakes, calculated using the UL.

inorganic phosphate. In the body, it is regulated by the kidneys and has an important structural role ${ }^{(30)}$. The inadequacies observed among adolescents can be explained by the higher requirements needed to support their intense period of growth ${ }^{(30)}$. Phosphate salts are commonly used by industries as additives, making processed foods good sources when ingested in significant amounts ${ }^{(30)}$. In the present study, the main contributors of P were meat, milk and Brazilian traditional foods. It is important to emphasise that, although most food sources have good P bioavailability, beans and whole-grain cereals contain a non-protoplasmic phytic acid that the human digestive system cannot hydrolyse; hence, this $\mathrm{P}$ is not directly available ${ }^{(30)}$.

In terms of $\mathrm{Zn}$ intake, in the present study, men were more susceptible to inadequate $\mathrm{Zn}$ intake than women. This difference may be reflective of the lower intake of $\mathrm{Zn}$-rich foods, combined with the higher sex-specific recommended requirements ${ }^{(45)}$. In addition, the highest inadequacy observed was among older adults, consistent with the findings of the Brazilian National Dietary Survey ${ }^{(6)}$. This age-related inadequacy of intake may be explained by the commonly observed monotony of the diet and difficulties older people experience with chewing, which impairs the consumption of foods such as meat. Foods that contributed towards $\mathrm{Zn}$ intake in the present sample varied from sources that are rich in $\mathrm{Zn}$ (red meat) to sources that have moderate (beans and milk) or poor (bread and white rice) $\mathrm{Zn}$ content. Consumption of whole grains could help achieve the recommended $\mathrm{Zn}$ intake. Inadequacies in dietary $\mathrm{Zn}$ can lead to impairment of the immune system, changes in oxidative stress and other alterations that can raise the risk of developing $\mathrm{NCD}^{(45)}$. 
Table 4. Dietary intakes of minerals with adequate intake (Al), their distribution and probability of adequacy in men and women residing in urban areas of Sao Paulo, according to life stage: Inquérito de Saúde de São Paulo (ISA-Capital) study, 2008

(Numbers, mean values and standard deviations)

\begin{tabular}{|c|c|c|c|c|c|c|c|c|c|c|}
\hline \multirow[b]{2}{*}{ Life stages ${ }^{*}$} & \multirow[b]{2}{*}{$n$} & \multirow[b]{2}{*}{ Mean } & \multirow[b]{2}{*}{ SD } & \multicolumn{5}{|c|}{ Percentiles of minerals intake } & \multirow[b]{2}{*}{ Al } & \multirow[b]{2}{*}{ Probability of adequate intake (\%) } \\
\hline & & & & 10 & 25 & 50 & 75 & 90 & & \\
\hline \multicolumn{11}{|l|}{ For men } \\
\hline $14-18$ years & 181 & 2438.7 & 757.6 & 1517.4 & 1959.4 & $2338 \cdot 3$ & $2908 \cdot 1$ & 3212.4 & 4700 & $1 \cdot 1$ \\
\hline $19-30$ years & 103 & $2418 \cdot 0$ & 811.4 & $1454 \cdot 1$ & 1811.6 & 2314.0 & 2831.8 & $3456 \cdot 4$ & 4700 & 1.0 \\
\hline $31-50$ years & 117 & 2254.4 & $585 \cdot 7$ & $1550 \cdot 6$ & 1913.0 & $2187 \cdot 7$ & 2563.1 & 3014.0 & 4700 & 0.0 \\
\hline $51-70$ years & 148 & $2290 \cdot 4$ & $729 \cdot 2$ & $1442 \cdot 1$ & $1860 \cdot 3$ & 2187.9 & $2577 \cdot 3$ & 3235.0 & 4700 & 0.7 \\
\hline$>70$ years & 84 & $2195 \cdot 2$ & $585 \cdot 2$ & $1530 \cdot 2$ & $1828 \cdot 1$ & $2122 \cdot 8$ & 2533.0 & $2926 \cdot 3$ & 4700 & 0.0 \\
\hline \multicolumn{11}{|l|}{$\mathrm{Mn}(\mathrm{mg} / \mathrm{d})$} \\
\hline 14-18 years & 181 & $3 \cdot 2$ & 1.0 & $2 \cdot 0$ & 2.5 & $3 \cdot 1$ & 3.8 & 4.6 & $2 \cdot 2 / 9 \cdot 0$ & 81.8 \\
\hline $19-30$ years & 103 & 3.0 & 0.9 & 1.8 & $2 \cdot 3$ & 2.9 & 3.6 & 4.3 & $2 \cdot 3 / 11 \cdot 0$ & 68.9 \\
\hline $31-50$ years & 117 & 3.0 & 0.9 & 1.8 & $2 \cdot 4$ & 2.9 & 3.7 & $4 \cdot 1$ & $2 \cdot 3 / 11 \cdot 0$ & $76 \cdot 9$ \\
\hline $51-70$ years & 148 & 2.9 & 0.9 & 1.9 & $2 \cdot 2$ & $2 \cdot 8$ & 3.4 & $4 \cdot 3$ & $2 \cdot 3 / 11 \cdot 0$ & 68.9 \\
\hline$>70$ years & 84 & $2 \cdot 7$ & 0.7 & 1.8 & $2 \cdot 2$ & $2 \cdot 7$ & $3 \cdot 1$ & 3.6 & $2 \cdot 3 / 11 \cdot 0$ & 64.3 \\
\hline \multicolumn{11}{|l|}{ For women } \\
\hline \multicolumn{11}{|l|}{$\mathrm{K}(\mathrm{mg} / \mathrm{d})$} \\
\hline $14-18$ years & 176 & 1911.1 & $568 \cdot 2$ & $1252 \cdot 7$ & $1508 \cdot 7$ & $1856 \cdot 0$ & $2206 \cdot 1$ & 2621.3 & 4700 & 0.0 \\
\hline $19-30$ years & 118 & 1875.6 & $468 \cdot 8$ & 1285.2 & 1563.5 & $1848 \cdot 1$ & $2206 \cdot 4$ & 2438.7 & 4700 & 0.0 \\
\hline $31-50$ years & 191 & $1802 \cdot 9$ & 460.9 & $1260 \cdot 3$ & $1507 \cdot 0$ & $1719 \cdot 9$ & $2005 \cdot 2$ & 2348.7 & 4700 & 0.0 \\
\hline $51-70$ years & 235 & 1834.7 & 458.8 & 1283.9 & 1483.5 & 1782.0 & $2160 \cdot 1$ & 2466.4 & 4700 & 0.0 \\
\hline$>70$ years & 158 & $1786 \cdot 0$ & $525 \cdot 2$ & $1287 \cdot 1$ & $1432 \cdot 1$ & 1681.0 & 2045.4 & $2506 \cdot 4$ & 4700 & 0.0 \\
\hline \multicolumn{11}{|l|}{$\mathrm{Mn}(\mathrm{mg} / \mathrm{d})$} \\
\hline $14-18$ years & 176 & 2.5 & 0.7 & 1.6 & $2 \cdot 0$ & $2 \cdot 4$ & $2 \cdot 9$ & 3.5 & $1 \cdot 6 / 9 \cdot 0$ & $90 \cdot 3$ \\
\hline $19-30$ years & 118 & 2.5 & 0.7 & 1.6 & $2 \cdot 0$ & 2.5 & $2 \cdot 9$ & 3.3 & $1 \cdot 8 / 11 \cdot 0$ & 83.1 \\
\hline $31-50$ years & 191 & 2.3 & 0.6 & 1.6 & 1.8 & $2 \cdot 2$ & 2.6 & 3.2 & $1.8 / 11.0$ & 79.1 \\
\hline $51-70$ years & 235 & 2.3 & 0.6 & 1.5 & 1.9 & $2 \cdot 2$ & $2 \cdot 7$ & $3 \cdot 1$ & $1 \cdot 8 / 11.0$ & $83 \cdot 8$ \\
\hline$>70$ years & 158 & $2 \cdot 1$ & 0.6 & 1.4 & 1.7 & $2 \cdot 0$ & $2 \cdot 2$ & $2 \cdot 7$ & $1.8 / 11.0$ & $77 \cdot 2$ \\
\hline
\end{tabular}

* 14-18 years: adolescence; 19-30 years: young adulthood; 30-50 years: middle age; 51-70 years: adulthood; >70 years: older adults ${ }^{(10)}$.

Inadequacies in the intake of $\mathrm{Cu}$ and Se have also been implicated as factors that may contribute to the increased risk of developing NCD; the role of both minerals as antioxidants would be one reason for this ${ }^{(45,46)}$. Se, when ingested in large amounts, can also increase the risk of diabetes, thus taking on an uncertain role ${ }^{(46)}$. In the present study, $\mathrm{Cu}$ and $\mathrm{Se}$, similar to $\mathrm{Zn}$, showed moderate-to-low inadequacies, and women had lower intakes. These findings can probably be explained by the lower amount of foods consumed by women, which consequently reduces the intake quantity of these minerals, which have the same dietary reference intake for both sexes.

Although liver, one of the most Cu-rich foods, has been listed among the contributors of this mineral, the other foods listed are considered to have moderate levels of $\mathrm{Cu}$, supporting the observed inadequacy. For Se, in addition to meat and rice, foods containing wheat contributed to the consumption of this mineral. Beans did not appear to contribute because the variety widely consumed in Sao Paulo - brown beans or 'carioquinha' beans - have the lowest Se concentrations $(0 \cdot 1 \mu \mathrm{g} / 100 \mathrm{~g})$ compared with other varieties such as black beans, $11.9 \mu \mathrm{g} / 100 \mathrm{~g}$; red beans, $3 \cdot 2 \mu \mathrm{g} / 100 \mathrm{~g}$; and white beans, $2 \cdot 6 \mu \mathrm{g} / 100 \mathrm{~g}^{(19)}$.

This present study confirms that socio-demographic and lifestyle factors influence the intakes of minerals differently. Sex and age were the main factors influencing mineral intake, showing that, although it is suggested that high cost and low access to foods might explain low mineral intake - because most mineral-rich foods are usually more expensive ${ }^{(2,7,47,48)}-$ other personal factors, including lifestyle, may influence mineral intake to an equal or greater extent. Being female, for example, in the present study showed one interesting aspect: decreased $\mathrm{Na}$ intake. The decreased $\mathrm{Na}$ intake among women was also observed in the Thai National Health Examination Survey IV, specifically in women $\geq 30$ years ${ }^{(49)}$. On the other hand, except for $\mathrm{Na}, \mathrm{Zn}, \mathrm{Cu}$ and $\mathrm{Se}$, older age was associated with increased mineral intake. This observation may reflect a better diet quality in older people as a response to minimise the diseases common of age, as described by Andrade ${ }^{(50)}$.

In the present study, the level of education of the household head and family income per capita were associated with intakes of different minerals. This highlights that these two factors impact the intake of minerals differently and independently, as has been suggested by some authors ${ }^{(7,51,52)}$. Although the education level of the household head was shown to influence $\mathrm{Na}$ and $\mathrm{Ca}$ intake, family income per capita was shown to influence only the intake of Se. Education may be a potential means of improving micronutrient intake; this information can be considered while developing public policies.

The adoption of healthier habits by participants engaging in sufficient physical activity was reflected by the increased intakes of $\mathrm{K}, \mathrm{Ca}$ and $\mathrm{Mg}$. Smoking, even in those categorised as former smokers, was negatively associated with mineral intake. The negative effects of smoking may lead to the development of unhealthier habits and by possible changes in gustatory capacity.

Doubtless, the global decline observed in the intake of whole grains ${ }^{(53)}$ directly affects the inadequacy of mineral intake, as 
Table 5. Main food contributors to dietary intake of minerals in residents of urban areas of Sao Paulo: Inquérito de Saúde de São Paulo (ISA-Capital) study, 2008 (Percentages of contribution)

\begin{tabular}{|c|c|c|c|c|c|c|c|c|c|c|c|c|c|c|c|c|c|c|}
\hline \multirow[b]{2}{*}{ Rank } & \multicolumn{2}{|l|}{ K } & \multicolumn{2}{|l|}{$\mathrm{Na}$} & \multicolumn{2}{|l|}{$\mathrm{Ca}$} & \multicolumn{2}{|l|}{$\mathrm{P}$} & \multicolumn{2}{|l|}{$\mathrm{Mg}$} & \multicolumn{2}{|l|}{$\mathrm{Zn}$} & \multicolumn{2}{|l|}{$\mathrm{Mn}$} & \multicolumn{2}{|l|}{$\mathrm{Cu}$} & \multicolumn{2}{|l|}{$\mathrm{Se}$} \\
\hline & Foods & $\%$ & Foods & $\%$ & Foods & $\%$ & Foods & $\%$ & Foods & $\%$ & Foods & $\%$ & Foods & $\%$ & Foods & $\%$ & Foods & $\%$ \\
\hline 1 & Brown beans & $12 \cdot 9$ & White rice & 19.5 & Milk & 23.7 & Beef meat & 11.5 & Brown beans & 13.9 & Beef meat & 28.9 & White rice & 30.5 & Beef liver & 23.8 & French bread & $16 \cdot 5$ \\
\hline 2 & Beef meat & 8.8 & French bread & 8.8 & Brown beans & 7.9 & Milk & 10.3 & White rice & 9.3 & White rice & 7.4 & Brown beans & 11.7 & Brown beans & 10.8 & White rice & 9.3 \\
\hline 3 & Milk & 7.9 & Beef meat & 7.8 & $\begin{array}{l}\text { Mozzarella } \\
\text { cheese }\end{array}$ & 5.6 & White rice & 7.2 & French bread & $5 \cdot 8$ & Brown beans & 5.9 & French bread & 8.9 & White rice & 9.1 & Whitefish & 8.4 \\
\hline 4 & Chicken & $4 \cdot 2$ & Brown beans & $7 \cdot 7$ & Pizza* & $4 \cdot 3$ & Chicken & $7 \cdot 2$ & Beef meat & 5.6 & Chicken & 5.6 & Wheat crackers & $4 \cdot 1$ & French bread & 4.9 & Chicken & 4.9 \\
\hline 5 & White rice & $2 \cdot 8$ & Chicken & 4.8 & French bread & 3.6 & Brown beans & 5.4 & Milk & 5.3 & Milk & 4.1 & Whole-wheat bread & 1.9 & Beef meat & 4.2 & Pizza* $^{\star}$ & 3.4 \\
\hline 6 & French bread & $2 \cdot 7$ & $\mathrm{Pizza}^{*}$ & 2.6 & $\begin{array}{l}\text { Process } \\
\text { cheese }\end{array}$ & 3.6 & French bread & 5.0 & Chicken & $\begin{array}{l}5.3 \\
4.3\end{array}$ & French bread & $\begin{array}{l}4.1 \\
3.7\end{array}$ & $\begin{array}{l}\text { Banana } \\
\text { Bana }\end{array}$ & 1.6 & Chicken & $\begin{array}{l}4.2 \\
1.9\end{array}$ & Milk & $\begin{array}{l}3 \cdot 4 \\
3 \cdot 2\end{array}$ \\
\hline 7 & Coffee & $2 \cdot 7$ & Salt & $2 \cdot 4$ & White rice & 3.1 & Whitefish & 3.0 & Whitefish & $2 \cdot 7$ & $\begin{array}{l}\text { Hamburger or } \\
\text { ground beef }\end{array}$ & $2 \cdot 1$ & Lettuce, green leaf & 1.2 & French fries & 1.7 & $\begin{array}{c}\text { Spaghetti } \\
\text { noodles with } \\
\text { tomato sauce }\end{array}$ & 2.9 \\
\hline 8 & Tomato, raw & 2.6 & Sausage $†$ & $2 \cdot 3$ & Yogurtł & $2 \cdot 2$ & $\begin{array}{l}\text { Process } \\
\text { cheese }\end{array}$ & $2 \cdot 8$ & Beer & $2 \cdot 6$ & Pork meat & 1.9 & $\begin{array}{l}\text { Spaghetti with } \\
\text { tomato sauce }\end{array}$ & 1.2 & $\begin{array}{c}\text { Cocoa or chocolate, } \\
\text { dry mix }\end{array}$ & 1.6 & $\begin{array}{l}\text { Esfiha with } \\
\text { cheese, meat }\end{array}$ & $2 \cdot 7$ \\
\hline 9 & Banana & $2 \cdot 6$ & $\begin{array}{l}\text { Process } \\
\text { cheese }\end{array}$ & 1.8 & $\begin{array}{c}\text { Cocoa or } \\
\text { chocolate, dry } \\
\text { mix }\end{array}$ & 1.9 & Pizza* & $2 \cdot 7$ & Banana & 1.9 & $\begin{array}{l}\text { Esfiha with } \\
\text { cheese, meat or } \\
\text { vegetables }\end{array}$ & 1.8 & Pizza* & 1.2 & $\begin{array}{l}\text { Spaghetti noodles } \\
\text { with tomato sauce }\end{array}$ & $1 \cdot 2$ & Beef meat & $2 \cdot 4$ \\
\hline 10 & Whitefish & $2 \cdot 1$ & $\begin{array}{l}\text { Salted } \\
\text { margarine }\end{array}$ & $1 \cdot 8$ & Ice cream & 1.6 & $\begin{array}{c}\text { Mozzarella } \\
\text { cheese }\end{array}$ & $2 \cdot 2$ & Coffee & 1.6 & Pizza* & 1.7 & Teał & $1 \cdot 1$ & Tomato, raw & $1 \cdot 1$ & Sausage† & 1.9 \\
\hline$\%$ Total & & 49.4 & & 59.5 & & 57.6 & & 57.4 & & 53.0 & & $63 \cdot 2$ & & 63.4 & & 60.2 & & $55 \cdot 6$ \\
\hline
\end{tabular}

* Varied salted flavours.

$\dagger$ Mixed meats.

‡ Varied flavours. 


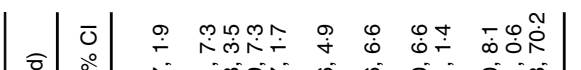

के

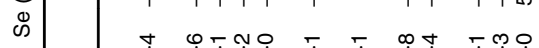

does the lower consumption of fruits and vegetables. Urgent consideration needs to be given to the question of how to approach the population in order to make individuals and the food industry aware of the necessity of adopting healthy lifestyle habits, in order to prevent diseases. From this perspective, dietary guidelines are important tools for health promotion. Such guidelines can encourage healthy eating habits that take into account changes in population eating habits, health conditions and advances in scientific knowledge ${ }^{(54)}$.

Globally, public policies for minerals have been more focused on $\mathrm{Fe}$, I and $\mathrm{Na}^{(33,55-57)}$. Some countries have also focused on $\mathrm{Zn}$ and $\mathrm{Ca}$, encouraging $\mathrm{Zn}$ and $\mathrm{Ca}$ fortification of foods ${ }^{(56,57)}$. Other minerals, whose intakes are frequently inadequate, such as $\mathrm{Mg}$, are not contemplated in these actions. This may be due to a paucity of data regarding the population intake of these minerals. New public policies that include the monitoring of more minerals are necessary to avoid mineral deficiencies and the consequences thereof.

A critical appraisal of the present study must to be taken into consideration. Evaluation of dietary intake is susceptible to both random and systematic errors. To minimise this bias, $24 \mathrm{HR}$ was conducted by a trained interviewer using standardised methods, as multiple-pass methods minimise the omission of possibly forgotten foods and standardise the level of detail for describing foods. Moreover, the interviewers were trained to communicate directly with the participants to minimise the influence of psychological determinants of misreporting ${ }^{(58)}$. In addition, the intra-individual variation was removed, and the effect of energy was considered for the associations tested. Finally, Se content in foods, especially in plants, can vary according to the availability of this mineral in the soil where the plant is grown; this may also influence the Se content in meats, depending on the animal feedstuff ${ }^{(46)}$. Therefore, it is important to recognise that, despite the corrections made in the database with data analysis of Brazilian foods ${ }^{(19)}$, the values obtained for all minerals may contain inaccuracies.

In conclusion, residents from urban areas of Sao Paulo have significantly inadequate intakes of most of the minerals assessed, taking all ages/life stages and both sexes into account. The high prevalence of inadequate intake raises concerns because of the association with impairments in vital functions and development of NCD. Moreover, the major foods contributing towards dietary intake of minerals were not the most mineral-rich food sources, but reflected the Brazilian cultural dietary pattern. Socio-demographic and lifestyle factors may influence the ability to reach the dietary reference intake of minerals. These findings may contribute to identification of population subgroups that are vulnerable to inadequate intake of minerals, to better target public health policies and to assist in monitoring established policies.

\section{Acknowledgements}

The authors are grateful to the ISA team and to the members of the Food Consumption Research Group. Particular thanks go to Prof. Chester Luiz Galvão César (Faculdade de Saúde Pública, Universidade de São Paulo) and Prof. Moisés Goldbaum 
(Faculdade de Medicina, Universidade de São Paulo) for ISA coordination, as well as to Dr Maria Cecilia Goi Porto Alves (Instituto de Saúde, Secretaria da Saúde, Governo do Estado de São Paulo) for her sample size analysis of the study population.

This study was supported by the Conselho Nacional de Desenvolvimento Científico e Tecnológico - CNPq (R. M. F., grant no. 473100/2009-6, D. M. M., grant no. 481176/2008-0); by the Fundação de Amparo à Pesquisa do Estado de São Paulo FAPESP (R. M. F. grant nos 2009/15831-0, 2012/22113-9); by the Prefeitura do Município de São Paulo (C. L. G. C., no grant number); and by the Coordenação de Aperfeiçoamento de Pessoal de Nível Superior - CAPES (C. H. S., no grant number). Funders cited had no role in the design, analysis or writing of this article.

C. H. S. performed the analysis and interpretation of data and drafted the article; M. d. M. F. and D. A. S. V. critically revised the analysis of data and the article; D. M. M. participated in designing the ISA study and critically revised the article; R. M. F. participated in designing the ISA study, supervising the analysis and critically revising the article. All authors read and approved the submitted version.

None of the authors has any potential conflicts of interest to declare.

\section{Supplementary material}

For supplementary material/s referred to in this article, please visit https://doi.org/10.1017/S0007114516004633

\section{References}

1. Araujo MC, Bezerra IN, Barbosa FS, et al. (2013) Macronutrient consumption and inadequate micronutrient intake in adults. Rev Saude Publica 47, Suppl. 1, 177S-189S

2. Verly Junior E, Cesar CL, Fisberg RM, et al. (2011) Socio-economic variables influence the prevalence of inadequate nutrient intake in Brazilian adolescents: results from a population-based survey. Public Health Nutr 14, 1533-1538.

3. Morimoto JM, Marchioni DM, Cesar CL, et al. (2012) Statistical innovations improve prevalence estimates of nutrient risk populations: applications in São Paulo, Brazil. I Acad Nutr Diet 112, 1614-1618.

4. Souza AM, Barufaldi LA, Abreu GA, et al. (2016) ERICA: intake of macro and micronutrients of Brazilian adolescents. Rev Saude Publica 50, Suppl. 1, 1s-15s.

5. Veiga GV, Costa RS, Araújo MC, et al. (2013) Inadequação do consumo de nutrientes entre adolescentes brasileiros (Inadequate nutrient intake in Brazilian adolescents). Rev Saude Pública 47, 212s-221s.

6. Fisberg RM, Marchioni DM, Castro MA, et al. (2013) Inadequate nutrient intake among the Brazilian elderly: National Dietary Survey 2008-2009. Rev Saude Publica 47, Suppl. 1, 222S-230S.

7. Vlismas K, Stavrinos V \& Panagiotakos DB (2009) Socio-economic status, dietary habits and health-related outcomes in various parts of the world: a review. Cent EurJ Public Health 17, 55-63.

8. Kaidar-Person O, Person B, Szomstein S, et al. (2008) Nutritional deficiencies in morbidly obese patients: a new form of malnutrition? Part B: minerals. Obes Surg 18, 1028-1034.

9. Mayen AL, Marques-Vidal P, Paccaud F, et al. (2014) Socioeconomic determinants of dietary patterns in low- and middle-income countries: a systematic review. Am J Clin Nutr 100, 1520-1531.

10. Institute of Medicine (2000) DRI Dietary Reference Intakes: Applications in Dietary Assessment. Washington, DC: National Academies Press.

11. Craig CL, Marshall AL, Sjostrom M, et al. (2003) International physical activity questionnaire: 12-country reliability and validity. Med Sci Sports Exerc 35, 1381-1395.

12. Haskell WL, Lee IM, Pate RR, et al. (2007) Physical activity and public health: updated recommendation for adults from the American College of Sports Medicine and the American Heart Association. Med Sci Sports Exerc 39, 1423-1434.

13. Nelson ME, Rejeski WJ, Blair SN, et al. (2007) Physical activity and public health in older adults: recommendation from the American College of Sports Medicine and the American Heart Association. Med Sci Sports Exerc 39, 1435-1445.

14. de Onis M, Onyango AW, Borghi E, et al. (2007) Development of a WHO growth reference for school-aged children and adolescents. Bull World Health Organ 85, 660-667.

15. World Health Organization (2000) Obesity: Preventing and Managing the Global Epidemic. Report of a WHO Consultation (WHO Technical Report Series no. 894). Geneva: WHO.

16. Lebrão ML \& Duarte YAO (2003) SABE - Saúde, Bem-estar e Envelhecimento - O Projeto Sabe no município de São Paulo: uma abordagem inicial (SABE - Health, Welfare and Aging The Sabe Project in the City of São Paulo: An Initial Approach). Brasília: Organização Pan-Americana da Saúde.

17. Raper N, Perloff B, Ingwersen L, et al. (2004) An overview of USDA's Dietary Intake Data System. J Food Compost Anal 17, 545-555.

18. Núcleo de Estudos e Pesquisas em Alimentação (2011) Tabela Brasileira de Composição de Alimentos - TACO (Brazilian Table of Food Composition - TACO), 4th ed. Campinas: NEPAUNICAMP. http://www.unicamp.br/nepa/taco/home

19. Ferreira KS, Gomes JC, Bellato CR, et al. (2002) Selenium content of Brazilian foods. Rev Panam Salud Publica 11, 172-177.

20. German Institute of Human Nutrition Potsdam-Rehbrücke (DIfE - Deutsches Institut für Ernährungsforschung) (2012) The Multiple Source Method (MSM). versão 1.0.1. Potsdam: Deutsches Institut für Ernährungsforschung. https://nugo.dife. $\mathrm{de} / \mathrm{msm}$

21. Block G, Dresser CM, Hartman AM, et al. (1985) Nutrient sources in the American diet: quantitative data from the NHANES II survey. I. Vitamins and minerals. Am J Epidemiol 122, 13-26.

22. StataCorp LP (2013) Stata Survey Data Reference Manual: Release 13. College Station, TX: StataCorp LP. www.stata.com/ manuals13/svy.pdf

23. Willett WC, Howe GR \& Kushi LH (1997) Adjustment for total energy intake in epidemiologic studies. Am J Clin Nutr $\mathbf{6 5}$, 1220S-1228S.

24. Institute of Medicine (2001) Dietary Reference Intakes for Vitamin A, Vitamin K, Arsenic, Boron, Chromium, Copper, Iodine, Iron, Manganese, Molybdenum, Nickel, Silicon, Vanadium, and Zinc. Washington, DC: National Academies Press.

25. Institute of Medicine (2005) Dietary Reference Intakes for Water, Potassium, Sodium, Chloride, and Sulfate. Washington, DC: National Academies Press.

26. Brown IJ, Tzoulaki I, Candeias V, et al. (2009) Salt intakes around the world: implications for public health. Int J Epidemiol 38, 791-813.

27. Welch AA, Fransen H, Jenab M, et al. (2009) Variation in intakes of calcium, phosphorus, magnesium, iron and potassium in 10 countries in the European Prospective 
Investigation into Cancer and Nutrition study. Eur J Clin Nutr 63, Suppl. 4, S101-S121.

28. Cogswell ME, Zhang Z, Carriquiry AL, et al. (2012) Sodium and potassium intakes among US adults: NHANES 2003-2008. Am J Clin Nutr 96, 647-657.

29. Powles J, Fahimi S, Micha R, et al. (2013) Global, regional and national sodium intakes in 1990 and 2010: a systematic analysis of $24 \mathrm{~h}$ urinary sodium excretion and dietary surveys worldwide. BMJ Open 3, e003733.

30. Institute of Medicine (1997) Dietary Reference Intakes for Calcium, Phosphorus, Magnesium, Vitamin D, and Fluoride. Washington, DC: National Academies Press

31. Souza AM, Bezerra IN, Pereira RA, et al. (2013) Dietary sources of sodium intake in Brazil in 2008-2009. I Acad Nutr Diet 113, 1359-1365.

32. World Health Organization (2012) A comprehensive global monitoring framework including indicators and a set of voluntary global targets for the prevention and control of noncommunicabale diseases. Second WHO discussion paper, WHO, Geneva, pp. 23. http://www.who.int/nmh/events/ 2012/discussion_paper2_20120322.pdf

33. Trieu K, Neal B, Hawkes C, et al. (2015) Salt reduction initiatives around the World - a systematic review of progress towards the global target. PLOS ONE 10, e0130247.

34. Nilson EAF, Jaime PC \& Resende DO (2012) Iniciativas desenvolvidas no Brasil para a redução do teor de sódio em alimentos processados (Initiatives developed in Brazil to reduce sodium content of processed foods). Rev Panam Salud Publica 34, 287-292.

35. Schmidt MI, Duncan BB, Azevedo e Silva G, et al. (2011) Chronic non-communicable diseases in Brazil: burden and current challenges. Lancet 377, 1949-1961.

36. Sales CH \& Pedrosa LFC (2006) Magnesium and diabetes mellitus: their relation. Clin Nutr 25, 554-562.

37. Pittas AG, Lau J, Hu FB, et al. (2007) The role of vitamin D and calcium in type 2 diabetes. A systematic review and metaanalysis. J Clin Endocrinol Metab 92, 2017-2029.

38. Adebamowo SN, Spiegelman D, Willett WC, et al. (2015) Association between intakes of magnesium, potassium, and calcium and risk of stroke: 2 cohorts of US women and updated meta-analyses. Am J Clin Nutr 101, 1269-1277.

39. Asemi Z, Saneei P, Sabihi SS, et al. (2015) Total, dietary, and supplemental calcium intake and mortality from all-causes, cardiovascular disease, and cancer: a meta-analysis of observational studies. Nutr Metab Cardiovasc Dis $\mathbf{2 5}$ 623-634

40. Bain LK, Myint PK, Jennings A, et al. (2015) The relationship between dietary magnesium intake, stroke and its major risk factors, blood pressure and cholesterol, in the EPICNorfolk cohort. Int J Cardiol 196, 108-114.

41. Choi MK \& Bae YJ (2015) Association of magnesium intake with high blood pressure in Korean adults: Korea National Health and Nutrition Examination Survey 2007-2009. PLOS ONE 10, e0130405.

42. Soedamah-Muthu SS, Ding EL, Al-Delaimy WK, et al. (2011) Milk and dairy consumption and incidence of cardiovascular diseases and all-cause mortality: dose-response meta-analysis of prospective cohort studies. Am J Clin Nutr 93, 158-171.
43. Gao D, Ning N, Wang C, et al. (2013) Dairy products consumption and risk of type 2 diabetes: systematic review and dose-response meta-analysis. PLOS ONE 8, e73965.

44. Schwingshackl L, Hoffmann G, Schwedhelm C, et al. (2016) Consumption of dairy products in relation to changes in anthropometric variables in adult populations: a systematic review and meta-analysis of cohort studies. PLOS ONE 11, e0157461.

45. Institute of Medicine (2001) Dietary Reference Intakes for Vitamin A, Vitamin K, Arsenic, Boron, Chromium, Copper, Iodine, Iron, Manganese, Molybdenum, Nickel, Silicon, Vanadium, and Zinc. Washington, DC: National Academies Press.

46. Institute of Medicine (2000) Dietary Reference Intakes for Vitamin C, Vitamin E, Selenium, and Carotenoids. Washington, DC: National Academies Press.

47. Yang X, Hsu-Hage BH, Tian H, et al. (1998) The role of income and education in food consumption and nutrient intake in a Chinese population. Asia Pac J Clin Nutr 7, 217-226.

48. Lim HS, Park YH, Lee HH, et al. (2015) Comparison of calcium intake status by region and socioeconomic status in Korea: the 2011-2013 Korea National Health and Nutrition Examination Survey. J Bone Metab 22, 119-126.

49. Satheannoppakao W, Kasemsup R, Inthawong R, et al. (2013) Sodium intake and socio-demographic determinants of the non-compliance with daily sodium intake recommendations: Thai NHES IV. J Med Assoc Thai 96, Suppl. 5, S161-S170.

50. Andrade SC (2013) Mudanças na qualidade da dieta e seus fatores associados em residentes do município de São Paulo em 2003-2008: estudo de base populacional (Changes in diet quality and its associated factors in residents of the city of São Paulo in 2003-2008: a population-based study). Doctorate, Faculdade de Saúde Pública da USP.

51. Araujo MC, Verly Junior E, Junger WL, et al. (2014) Independent associations of income and education with nutrient intakes in Brazilian adults: 2008-2009 National Dietary Survey. Public Health Nutr 17, 2740-2752.

52. Si Hassen W, Castetbon K, Cardon P, et al. (2016) Socioeconomic indicators are independently associated with nutrient intake in French adults: a DEDIPAC study. Nutrients $\mathbf{8}, 158$.

53. Micha R, Khatibzadeh S, Shi $\mathrm{P}$, et al. (2015) Global, regional and national consumption of major food groups in 1990 and 2010: a systematic analysis including 266 country-specific nutrition surveys worldwide. BMJ Open 5, e008705.

54. World Health Organization (2004) Global Strategy on Diet Physical Activity and Health. Geneva: WHO.

55. World Health Organization (2016) Vitamin and Mineral Nutrition Information System (VMNIS). Geneva: WHO. www. who.int/vmnis/en/

56. World Health Organization (2006) Guidelines on Food Fortification with Micronutrients. Geneva: WHO.

57. Darnton-Hill I \& Nalubola R (2002) Fortification strategies to meet micronutrient needs: success and failures. Proc Nutr Soc 61, 231-241.

58. Poslusna K, Ruprich J, de Vries JHM, et al. (2009) Misreporting of energy and micronutrient intake estimated by food records and 24 hour recalls, control and adjustment methods in practice. Br J Nutr 101, Suppl. 2, S73-S85. 